\title{
メタリック調射出成形品における 光輝材混合比の画像解析による識別
}

\author{
須 田高 史 $^{* 1} \cdot$ 黒 岩 広 樹*1 福 島 祥 夫*1 $・$ 小宅 勝*1 \\ 高岡登志仁*2. 寺内 文 雄*3
}

\section{Identification of Mixing Ratios of Metallic Flakes in Metallic Color Products Injection-Molded by Image Analysis}

\author{
Suda, Takashi*1/Kuroiwa, Hiroki*1/Fukushima, Yoshio*1/Oyake, Masaru*1/ \\ Takaoka, Toshihito*2/Terauchi, Fumio*3
}

\begin{abstract}
The exterior components are often painted with metallic color. However, painting increases the cost and environmental impact. So, manufacturing technology that makes metallic-colored plastic parts by injection molding without painting is being developed by many companies. But color unevenness hinders commercialization. In this study, we focused on the dispersion of metallic flakes that cause uneven color in metallic molding and investigated in order to evaluate the dispersion. We made test pieces with different sizes of metallic flakes by injection-molding and evaluated influence of proportion of metallic flakes on the qualities of plastic parts. We took the test pieces using a CCD microscope and compared the results of image analysis. We selected skewness (SKEW), angular second moment (ASM) and entropy (ENT) as values that indicate the features of the image. The following conclusions were obtained. (1) When the ratio of metallic flakes increased, flakes that are present at a position near surface increased. In the gray level histogram, SKEW decreased. The results of the analysis by co-occurrence matrix, ENT increased. (2) When the size of metallic flakes increased, SKEW increased. The results of the analysis by co-occurrence matrix, ASM increased. (3) It was considered that the difference of the ratio and the size of metallic flakes affected the results of image analysis. (4) It was suggested that gray level histogram and co-occurrence matrix were useful for evaluating the dispersion of metallic flakes.
\end{abstract}

Key words : Metallic, Image analysis, Gray level histogram, Co-occurrence matrix, Injection molding

\section{1.緒言}

自動車や情報家電等の外観部品においては, 高付加価值

*1 群馬県立群馬産業技術センター

Gunma Industrial Technology Center

前橋市亀里町 884-1（テ379-2147）

884-1, Kamesato, Maebashi, Gunma, 379-2147, Japan suda-tak@pref.gunma.lg.jp

*2 (秼柴田合成

Shibata Gosei Co., Ltd.

甘楽郡甘楽町小幡 270-3（开370-2202）

270-3, Obata, Kanra, Kanra, Gunma, 370-2202, Japan

*3 千葉大学大学院 工学研究科

Graduate School of Engineering, Chiba University

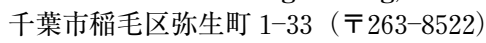

1-33, Yayoi, Inage, Chiba, Chiba, 263-8522, Japan

2013. 11.22 受理
化を目的としてメタリック塗装を施す場合が多い.メ夕 リック塗装においては，塗料にアルミニウム粉を混合して 金属光沢を付与している ${ }^{1)}$. 金属光沢を付与することに よって製品に高級な印象を持たせることが可能であり， 様々な分野に使用されているため, 塗料・塗装の両面にわ たって技術開発が行われている ${ }^{2}$.

しかしながら，塗装はコストを押し上げる要因となって おり，また揮発性有機化合物を発生することから，環境に も悪影響を及ぼしている．塗料そのものを製造するときよ りも塗装で使用されるときのほうが環境への負荷が大きい と考えられており，国内外において揮発性有機化合物の規 制が行われ，その対応が求められている ${ }^{3)}$.

そこで，光輝材を樹脂に混合したものを射出成形するこ とにより，塗装工程を省きつつメタリック調の外観を発現 する部品の生産技術の開発が行われている（以下メタリッ 
ク成形 ${ }^{4)}$ と称する). 具体的には, メタリック調の光沢を出 すための金属粉である光輝材（アルミフレーク）を樹脂に 混合させて成形を行う。

メタリック成形は加飾技術の一つに位置づけられ，様々 な技術開発が行われているが，実用化はまだ不十分であり， 実用化を阻害している大きな要因として, 色ムラの発生が ある. 代表的な原因として成形品内部における光輝材配向 の乱れが挙げられる. 光輝材配向の乱れはウェルドライン 部での発生が多いことから, ウェルドラインの解消に効果 的であるとされている金型温度制御技術 ${ }^{5)}$ - 12) 成形へ適用するための技術開発が行われている。 また，射 出成形機内部で発生した光輝材の凝集解消を目的とした金 型内における流路の検討 ${ }^{13}$ も行われている.

以上のように，メタリック成形の生産技術については 様々な研究開発がなされているが, メタリック成形が市場 に受け入れられる技術として発展していくためには，生産 技術の高度化のみでは不十分であると考えられる。メ夕 リック成形の実用化を阻む最大の要因が色ムラであること を考慮すれば，色ムラを定量的に評価する手法の確立が生 産技術の研究開発とともに必要である. 色ムラが定量的に 評価できれば生産技術の改善効果も定量的に示すことが可 能になり，生産技術の発展を促進することができる。また， 現在はメタリック成形品の品質として光輝材の粒径や混合 比といった材料の仕様が提示されることが多いが，色ムラ が製品形状やゲートに大きく左右されることから，材料の 仕様のみでは成形品の品質表示としては不十分であると考 えられる，材料の仕様のみならず，金型によって形状を付 与された後の成形品から得られる特性值によって品質を定 めることが重要である. 成形品の特性值で品質が定まれば 品質管理も定量的に行うことができ, 更にはメタリック成 形品の仕上がりを設計者やデザイナーが図面等で定量的に 指示することも可能になる。

そこで, 本研究ではメタリック成形品の品質を定量的に 定めるための基礎的な検討を行った. 色ムラを定量的に評 価するという観点におけるこれまでの研究は，メタリック 成形品の評価として, 成形品の光沢を計測した事例 ${ }^{14)}$ や X 線 CT 用いた事例 ${ }^{15)}$ が挙げられる。 また，メタリック塗 装の分野では, 塗装ムラの定量的な評価として発光素子か ら塗膜に照射された光を受光して解析するもの ${ }^{16)}$ や測色結 果を利用するもの ${ }^{17)}$ といった巨視的な評価方法が検討され ている.さらに,メタリック成形以外の成形品におけるフィ ラーの配向評価に関しては, 短繊維強化プラスチック内部 における繊維配向の評価として X 線透過像 ${ }^{18}$ や超音波顕微 鏡 ${ }^{19)}$ を用いた事例も挙げられる。

これまで述べたように，メタリック成形品の色ムラは, 光輝材配向の乱れによって発生すると考えられるため, 本 研究では, CCD マイクロスコープ画像から得られる画像 情報を用い, 成形品表面近傍における光輝材の局所的な分 散状態の観点からメタリック成形品の品質を評価すること を目的とする. 本方法の特長として, 以下の点が挙げられ る.（1）装置が小型であるため, 製造現場においても作業 者による評価を実施できる。（2）X線等を使用する設備に 比べて装置が安価であるため, 中小企業等においても導入 が容易である。（3）小型カメラを用いた画像処理の自動化
に本技術を展開できればインライン計測への発展が期待で きる。

光輝材の局所的な分散状態を評価するための基礎的な検 討として, 数種類の粒径の光輝材に対して, 混合比を変化 させた際の画像解析結果を比較した. メタリック成形品に おいては, 混合した光輝材が成形品の内部よりも表面近傍 に集まるほうが加飾効果を高めると思われるが，基礎的な 検討として混合比を増やすことで表面近傍の光輝材を増加 させることを考えた。 また，混合比による光輝材分散状態 の変化が画像解析によって識別できれば, その手法を色么 ラ評価へ展開することも検討できると考えた。

画像解析の方法として濃度ヒストグラムと同時生起行列 を使用した。濃度ヒストグラムとは輝度ヒストグラムとも 呼ばれ，これまでに砥石の目詰まり評価 ${ }^{20)} へ の$ 利用が試み

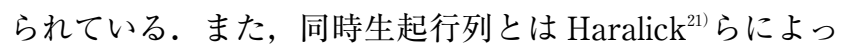
て提案された画像解析の手法で，これまでにラッピング加 工後における鏡面等の評価 ${ }^{22)}$, 織物のしわ評価 ${ }^{23)}$ やアラ イン加工の仕上げ面評価 ${ }^{24}$ への適用が試みられている. 以 上のようにこれらの手法は様々な外観評価に用いられてい るが，メタリック成形品を含めた複合材料におけるフィ ラーの分散状態評価に用いられたことはない.このため, 濃度ヒストグラムと同時生起行列の光輝材分散状態評価へ の適用可能性を検討した。

本研究の手順は次のとおりである.はじめに光輝材の混 合比と粒径を変化させた数種類の試験片における外観や断 面の画像を撮影した。次に画像解析を用いて外観拡大画像 の特性值を算出した。 そして算出結果を比較して光輝材の 混合比と粒径の変化が外観拡大画像の特性值に及ぼした影 響について考察した.

\section{2. 実験方法}

\section{1 供試材料と成形品}

供試材料は, ベース材として ABS（日本エイアンドエ ル(株)製クララスチック MTH-2) と, 光輝材としてマスター バッチ（東洋アルミニウム株製）を混合した. ベース材に 対するマスターバッチの混合比は, 重量比で $1.5 \%$ と $3.0 \%$ の 2 種類とした。 またマスターバッチに含まれてい る光輝材の寸法は表 1 に示す 3 種類とした.

成形品の形状は JIS K 7139 で規定するダンベル形引張 試験片（タイプ A 12）に準拠し, 片側からの 1 点ゲート で成形した. 本研究においては光輝材の分散状態の把握を 主な目的としたことから, ベース材の色は乳白色とし, 試 験片の色は無彩色のシルバーメタリックとした.

\section{2 撮影方法}

本研究においては, 画像解析用の外観拡大画像と比較の ための外観写真および断面拡大画像を撮影した。

画像解析用の外観拡大画像については, 試験片平行部の

Table 1 Aluminum flake size

\begin{tabular}{c|c}
\hline \hline Diameter $(\mu \mathrm{m})$ & Thickness $(\mu \mathrm{m})$ \\
\hline 5 & 0.2 \\
\hline 60 & 7.0 \\
\hline 90 & 7.3 \\
\hline
\end{tabular}


中央付近を CCD マイクロスコープ（本体：(株)キーエンス 製 VHX-500，レンズ：(株キーエンス製 VH-Z 100 R）を 使用して撮影した。各比率および各粒径ごとに同一ロット の 3 個の試験片を用意し，1条件あたり 6 枚の画像を取得 した．撮影個所の概略を図 1 の上段に示す。補助照明を用 いて光輝材と樹脂部の明暗差が明確になるように調整した. また，得られた画像を $1024 \times 1024$ 画素にトリミングした。 撮像条件についてであるが, 光輝材寸法に応じて解像度 を調整することが望ましいと考え, 粒径に応じて倍率を変 更した画像を用いて解析した. $5 \mu \mathrm{m}$ については粒径が小 さいため, 倍率を 400 倍とした. 撮像領域の大きさが約 $0.5 \times 0.5 \mathrm{~mm}$ であることから 1 画素あたりの長さは約 $0.49 \mu \mathrm{m}$ である.また, $60 \mu \mathrm{m}$ と $90 \mu \mathrm{m}$ については倍率 を 100 倍とした. 撮像領域の大きさが約 $2.0 \times 2.0 \mathrm{~mm}$ で あることから 1 画素あたりの長さは約 $1.95 \mu \mathrm{m}$ である. 本研究において想定している色ムラは肉眼で判別できるレ ベルで, サイズは太さ $0.1 \mathrm{~mm}$ 前後の筋状の色むらである ことから, 必要な分解能は確保できていると判断した.

比較のための外観写真については, デジタルカメラ（カ シオ計算機侏製 EX-ZR 200）を用いてマクロ撮影を行い, 上記の試験片の中から代表的な画像を 1 条件あたり 1 枚取 得した。また断面拡大画像については, 上記の試験片と同 一ロットの別の試験片を用意し, 樹脂に包埋して研磨した 後に CCD マイクロスコープ (本体 : (株キーエンス製 VHX -500，レンズ：(株キーエンス製 VH-Z 20）を用いて断面 観察を行った。試験片中央部より表面側の部位を撮影した. 断面については画像解析せずに目視による比較のみを目的 としたため撮像倍率を 200 倍で統一した. 撮影個所の概略 を図 1 の下段に示す.

\section{3 画像解析方法}

本研究では，既に述べたように，画像解析の方法として これまでメタリック成形品の評価に適用されたことがない
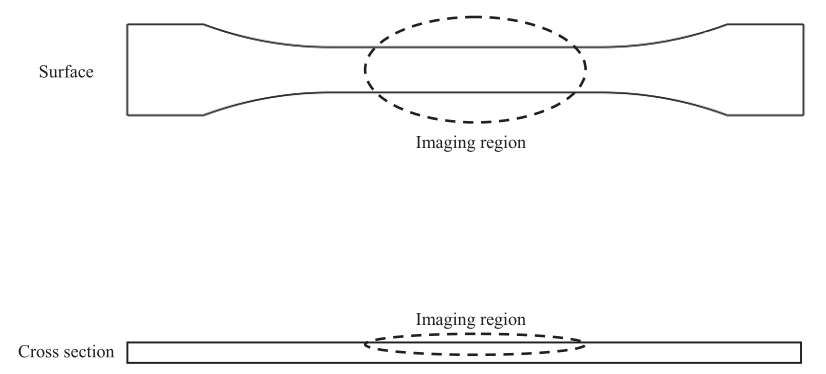

Fig. 1 Test piece
濃度ヒストグラムと同時生起行列を使用した。具体的には, 画像解析ソフトウェア（デジタルビーイングキッズ社製 PopImaging）を用いて，画像を解析した．解析方法は， はじめに，カラー画像をグレースケール（256 階調）に変 換して濃度ヒストグラムを作成した。また，32諧調に変 換したグレースケール画像に対して同時生起行列を求めた. 濃度ヒストグラムとは, 元の画像から, 各画素の濃度 (明 るさ）の值を読み取り, 各濃度の度数（画素の数）を数え てヒストグラムで表したものである．ヒストグラムの分布 形状を見ることによって特徵を把握できるとともに，分布 の特徵を示す統計的な指標を算出できる. 代表的な指標と しては，分布形状に関するものとしてピークの数，大きさ や位置, 統計的なものとして平均, 分散, 歪度および尖度 が挙げられるが，本研究においては，形状については分布 の最大值を示しているピークの值（Peak）を比較し，統 計的なものについては分布形状の左右対称性を示すとされ る歪度 (Skewness, SKEW) を算出して比較した。 256 階調で総画素数が $1024 \times 1024$ の画像の場合, 歪度は次式 で与えられる。

$$
\text { SKEW }=\frac{\sum_{i=0}^{255}(i-m)^{3} \frac{n(i)}{1024^{2}}}{\mathbf{s}^{3}}
$$

ここで, $i$ : 濃度, $m$ : ヒストグラムの平均值, $n(i):$ 濃 度が $i$ である画素数, $\mathrm{s}$ ：ヒストグラムの標準偏差である. 分布形状が左右対称になると歪度がゼロとなり, 歪度が正 の值になれば右に裾が長い（ピークが左に偏った）分布で あるということができる。サンプル数が 50 個の分布にお ける歪度の計算例を図 2 に示す。

同時生起行列とは, ある画像において, 濃度 $i$ の画素か ら一定の距離と角度 $\delta=(\mathrm{r}, \boldsymbol{\theta})$ だけ離れた位置にある画 素の濃度が $j$ となる確率 $P(i, j)$ を要素とする行列である. 本研究では，隣接する画素同士（すなわち $\mathrm{r}=1$ ）の関係 に着目して, 横方向 $\left(\theta=0^{\circ}\right)$, 右斜め方向 $\left(\theta=45^{\circ}\right)$ 縦方 向 $\left(\theta=90^{\circ}\right)$ および左斜め方向 $\left(\theta=135^{\circ}\right)$ の 4 つの方向 について同時生起行列を作成した， 4 諧調で $4 \times 4$ 画素の 画像における，隣接する横方向の画素同士の関係 $\delta=$ $\left(1 ， 0^{\circ}\right)$ を同時生起行列にまとめた計算例を図 3 に示す. 具体的な計算方法は, (1)元の画像に対して, (2)各画素の濃 度を求め, (3)隣接する画素同士の濃度の関係を行列の形式 にまとめ，(4)得られた行列の成分の総和が 1 になるように 正規化して同時生起行列を作成する.
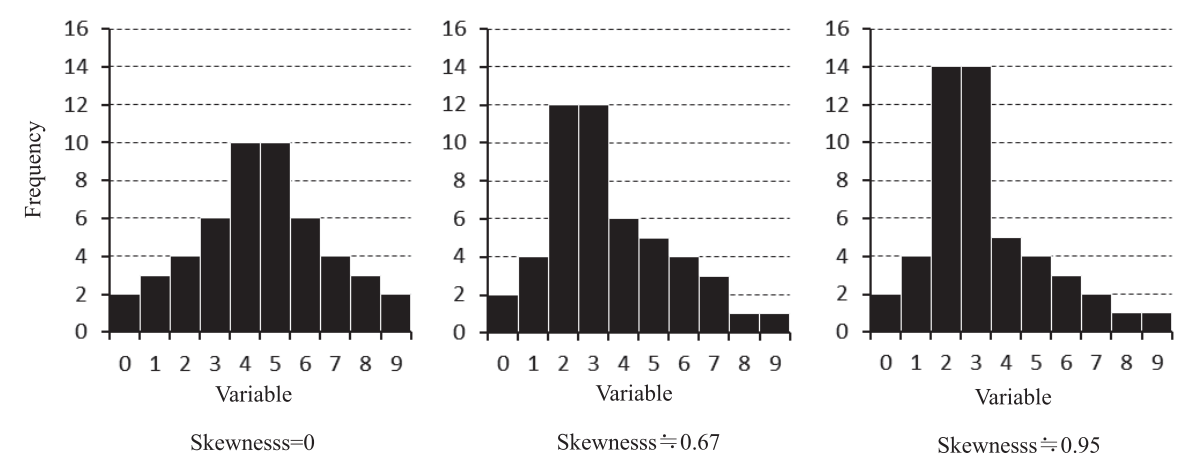

Fig. 2 Examples of skewness 
同時生起行列の成分を用いて特徴量が算出でき, 本研究 では角 2 次モーメント (Angular second moment, ASM) とエントロピー（Entropy，ENT）を特徴量として用いた. 画像の諧調数を 32 に変換した後, 以下の式によって算出 した（画像の諧調数は 32 とする）.

$$
\begin{gathered}
\mathrm{ASM}=\sum_{i=0}^{31} \sum_{j=0}^{31} P(i, j)^{2} \\
\mathrm{ENT}=-\sum_{i=0}^{31} \sum_{j=0}^{31} P(i, j) \ln P(i, j)
\end{gathered}
$$

4 つの方向の同時生起行列から角 2 次モーメントとエント ロピーが 4 個ずつ算出されるため， 4 個の平均值をある粒 径および混合比における角 2 次モーメントとエントロピー の值とした. 4 諧調で $4 \times 4$ 画素の画像における, 同時生 起行列および隣接する横方向の角 2 次モーメントとエント ロピーの算出例を表 2 に示す。表 2 において, 左側は単一 色の画像で全ての画素が同じ濃度になっている事例を示し， 右側は様々な濃度の画素が分散している事例を示している. 左側のように同時生起行列において特定の濃度対が多く現 れるとき，すなわち，同時生起行列のある要素が大きな值 になるときに角 2 次モーメントの值が大きくなる．また， 右側のように同時生起行列において各濃度対が一様に存在 するとき, すなわち, 同時生起行列の各要素が近い值にな るときにエントロピーの值が大きくなる.

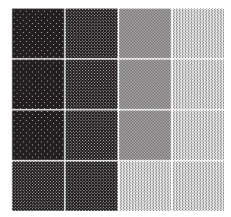

(1)The original image $\begin{array}{llll}0 & 1 & 2 & 3\end{array}$

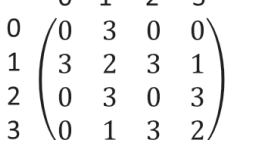
(3) The relationship of the gray level of adjacent pixels
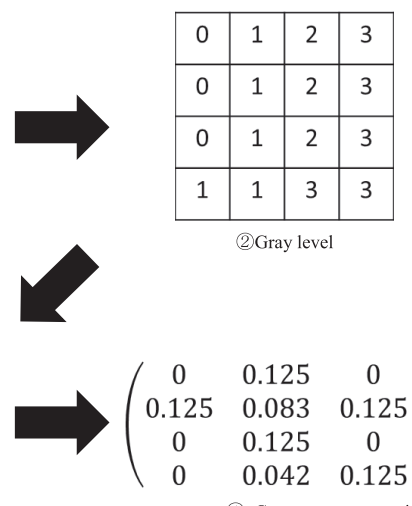

$0.125 \quad 0$

$0 \quad 0$ $\begin{array}{lll}0.083 & 0.125 & 0.042\end{array}$ $\begin{array}{lll}0.125 & 0 & 0.125\end{array}$ $\left.\begin{array}{lll}0.042 & 0.125 & 0.083\end{array}\right)$

(4) Co-occurrence matrix

Fig. 3 Example of calculation of co-occurrence matrix

\section{3. 実験結果と考察}

\section{1 外観拡大画像, 外観および断面拡大画像の観察結} 果

図 4 にマイクロスコープで撮影した試験片の外観拡大画 像の一例を, 図 5 に外観のマクロ撮影画像を, そして図 6 に断面拡大画像を示す.

外観拡大画像およびマクロ撮影画像の観察結果から，粒 径が $5 \mu \mathrm{m}$ の試験片は光輝材粒子が肉眼では判別できない レベルとなり, $60 \mu \mathrm{m}$ と $90 \mu \mathrm{m}$ は肉眼でも光輝材粒子が 判別できるレベルとなった. 混合比が多くなると光輝材粒 子の分布が相対的に密になり，また粒径が大きくなると粒 子間の隙間が相対的に大きくなった.

断面拡大画像を見ると, 写真下端側の試験片コア層に相 当する部分において光輝材が多く集まっており，光輝材が 集中している部分を外れると試験片表面のスキン層までほ ぼ均一に光輝材が分布した。混合比の増加に応じて粒子が 密になり, 粒径が大きくなると粒子間の隙間が相対的に大 きくなることが確認できた. 以上より，今回の試験片にお いては, 光輝材の混合比が増えたことによって表面近傍の 粒子が増えたことが示唆された。

\section{2 濃度ヒストグラムによる解析結果}

図 7 に濃度ヒストグラムの一例を示す．横軸に画素の濃 度（明るさ）を記し, 縦軸に各濃度における画素数を全体 の画素数に対する百分率で記した. 原点付近は画像内の暗 い領域の比率，横軸の值が 125 前後となる中間付近は灰色 領域の比率を示し, 横軸の值が 250 前後となる最大值付近 は明るい領域の比率を示している.

図 8 に濃度ヒストグラムにおけるピークの大きさを示す. 各条件について 6 枚の画像解析結果の平均值と標準偏差を 示した. 粒径は同一で混合比が異なる条件の平均值同士を 比較した結果, 粒径 $5 \mu \mathrm{m}$ においては危険率 $1 \%$ の有意 差が見られ，粒径 $60 \mu \mathrm{m}$ においては危険率 $5 \%$ の有意差 が見られた. 粒径 $90 \mu \mathrm{m}$ においては平均值が低下したも のの有意差は認められなかった. 粒径 $90 \mu \mathrm{m}$ においては 標準偏差も大きかった.すなわち粒径 $5 \mu \mathrm{m}$ と $60 \mu \mathrm{m}$ に おいては, 混合比が増加した結果，ピークの值が低下した。

混合比は同一で粒径が異なる条件の平均值同士を比較し た結果，粒径 $60 \mu \mathrm{m}$ 混合比 $1.5 \%$ と $90 \mu \mathrm{m}$ 混合比 $1.5 \%$ の比較においては有意差が見られなかったものの, その他

Table 2 Examples of co-occurrence matrix

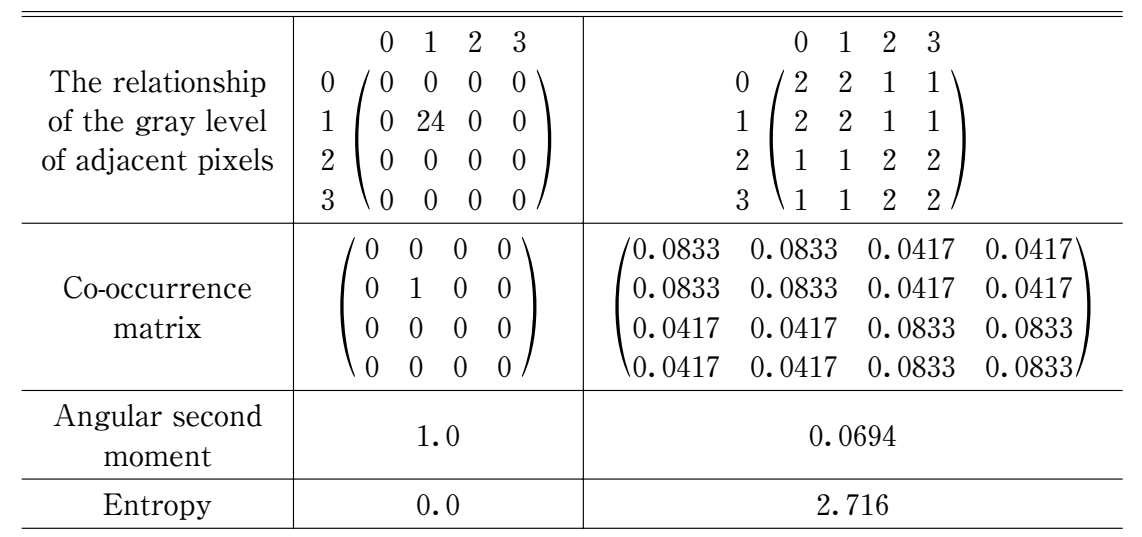




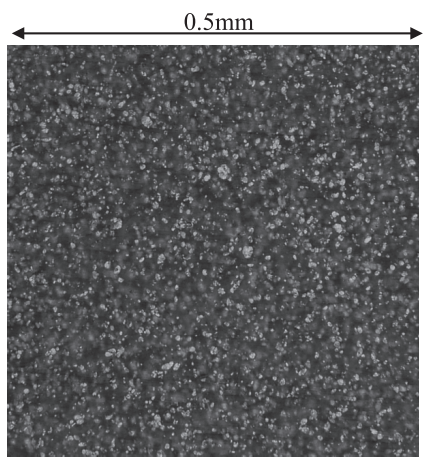

$5 \mu \mathrm{m}, 1.5 \%(\times 400)$

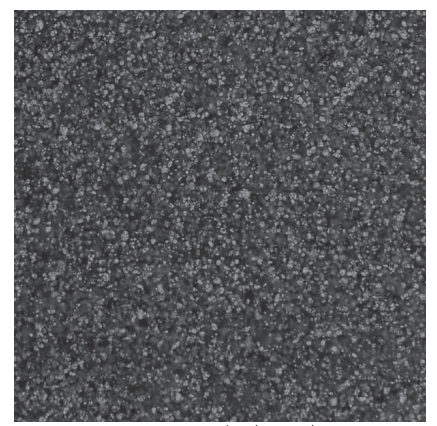

$5 \mu \mathrm{m}, 3.0 \%(\times 400)$
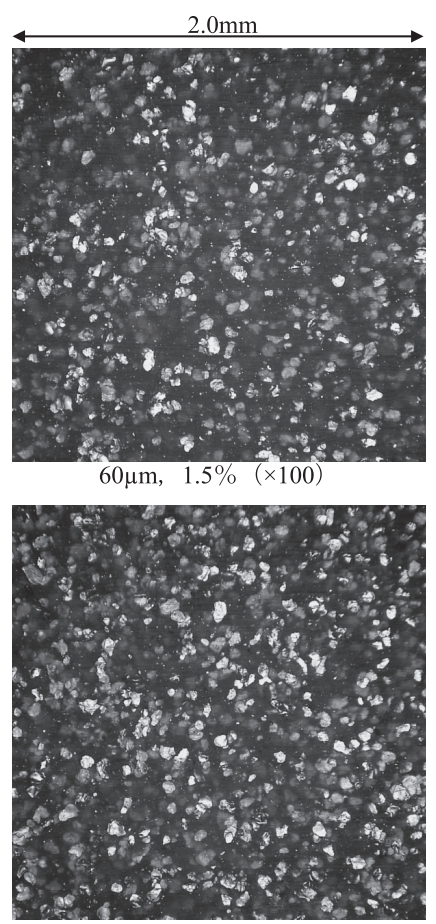

$60 \mu \mathrm{m}, 3.0 \%(\times 100)$

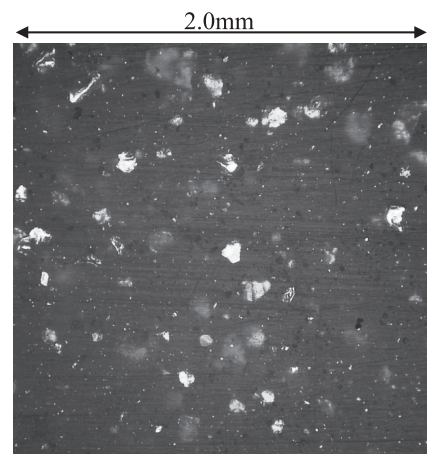

$90 \mu \mathrm{m}, \quad 1.5 \%(\times 100)$

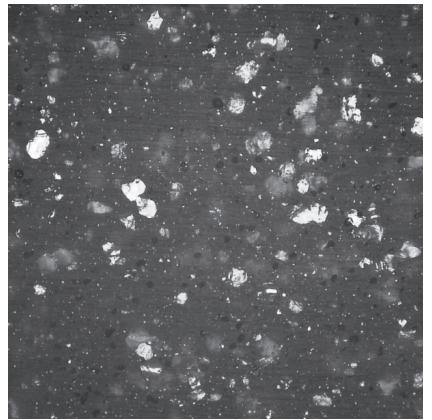

$90 \mu \mathrm{m}, \quad 3.0 \%(\times 100)$

Fig. 4 Micrographs of surface of test pieces

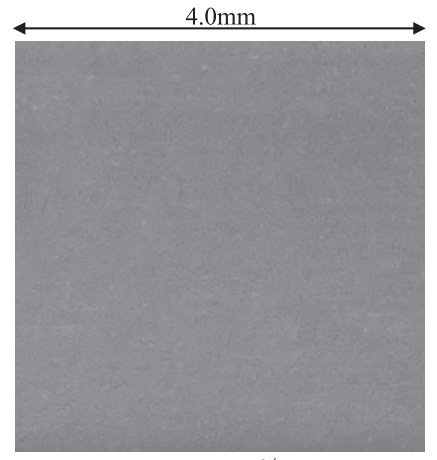

$5 \mu \mathrm{m}, \quad 1.5 \%$

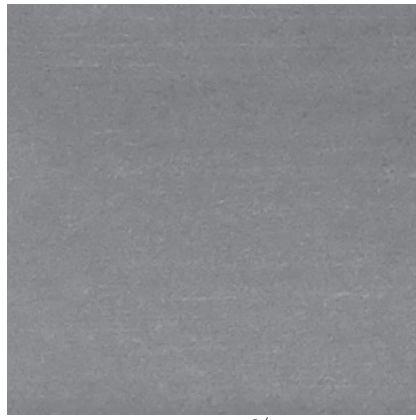

$5 \mu \mathrm{m}, 3.0 \%$

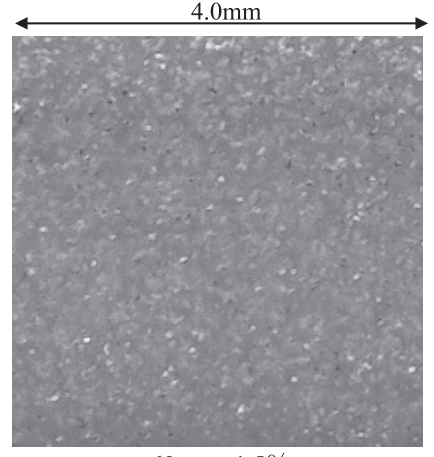

$60 \mu \mathrm{m}, \quad 1.5 \%$

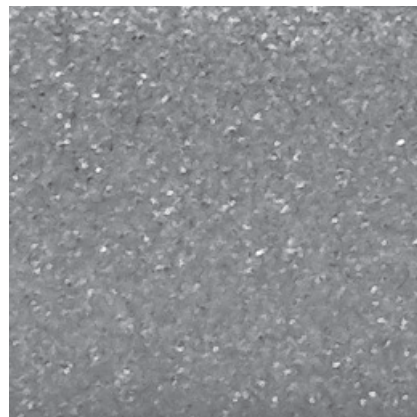

$60 \mu \mathrm{m}, \quad 3.0 \%$

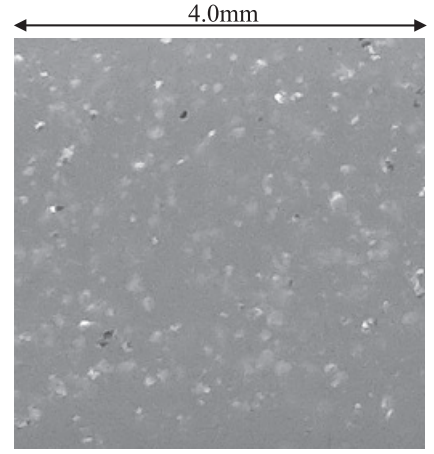

$90 \mu \mathrm{m}, \quad 1.5 \%$

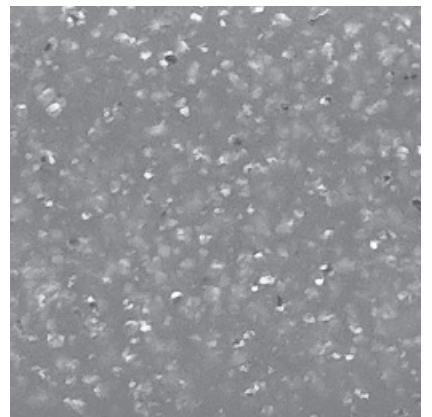

$90 \mu \mathrm{m}, 3.0 \%$

Fig. 5 Photographs of surface of test pieces

の条件の比較については有意差が見られた。

図 9 に歪度の算出結果を示す. 各条件について 6 枚の画 像解析結果の平均値と標準偏差を示した．粒径は同一で混 合比が異なる条件の平均值同士を比較した結果，全ての粒 径において危険率 $1 \%$ の有意差が見られた。すなわち全 ての粒径において, 混合比の増加に伴って, 歪度の值が減 少した。

混合比は同一で粒径が異なる条件の平均值同士を比較し た結果，粒径 $5 \mu \mathrm{m}$ 混合比 $1.5 \%$ と $60 \mu \mathrm{m}$ 混合比 $1.5 \%$ の
比較においては危険率 $5 \%$ の有意差が見られ，その他の 条件の比較については危険率 $1 \%$ の有意差が見られた。 すなわち粒径の増大に伴って歪度の值が増加した。

図 8〜9 の解析結果と図 4〜6の画像との関係性を検討す ると，以下のように考えられる．混合比の変化に関する影 響に関しては，混合比が増加すると表層のみならず内部の 粒子も増加して, 表面からの画像として見たときには様々 な濃さの粒子として画像に表れ，また粒子間の隙間も少な い画像となった，様々な濃さの粒子が増えて隙間が減った 


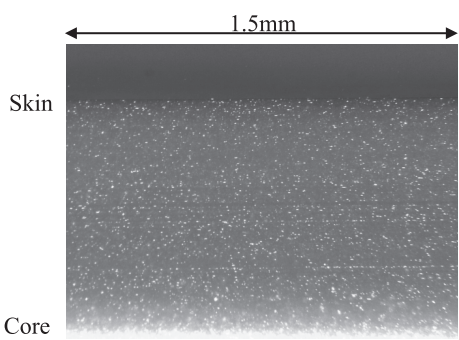

$5 \mu \mathrm{m}, \quad 1.5 \%(\times 200)$

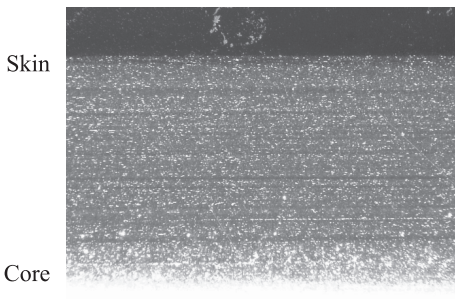

$5 \mu \mathrm{m}, \quad 3.0 \%(\times 200)$

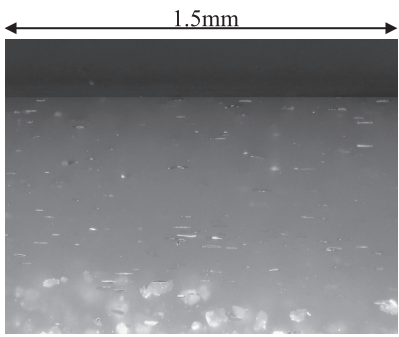

$60 \mu \mathrm{m}, 1.5 \%(\times 200)$

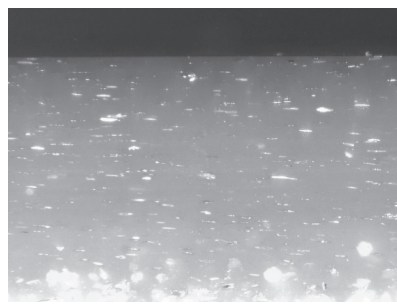

$60 \mu \mathrm{m}, 3.0 \% \quad(\times 200)$

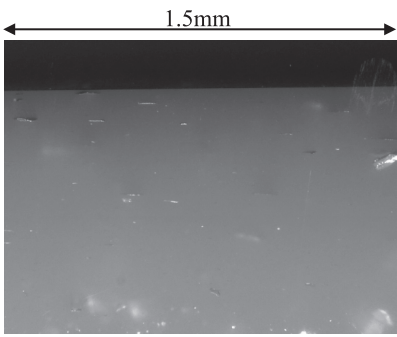

$90 \mu \mathrm{m}, \quad 1.5 \%(\times 200)$

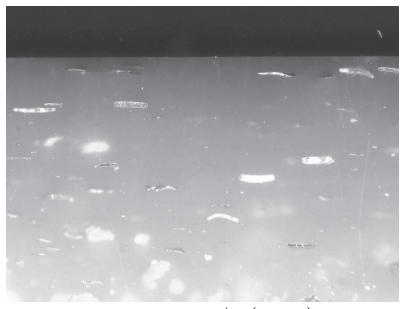

$90 \mu \mathrm{m}, \quad 3.0 \% \quad(\times 200)$

Fig. 6 Micrographs of cross section of test pieces
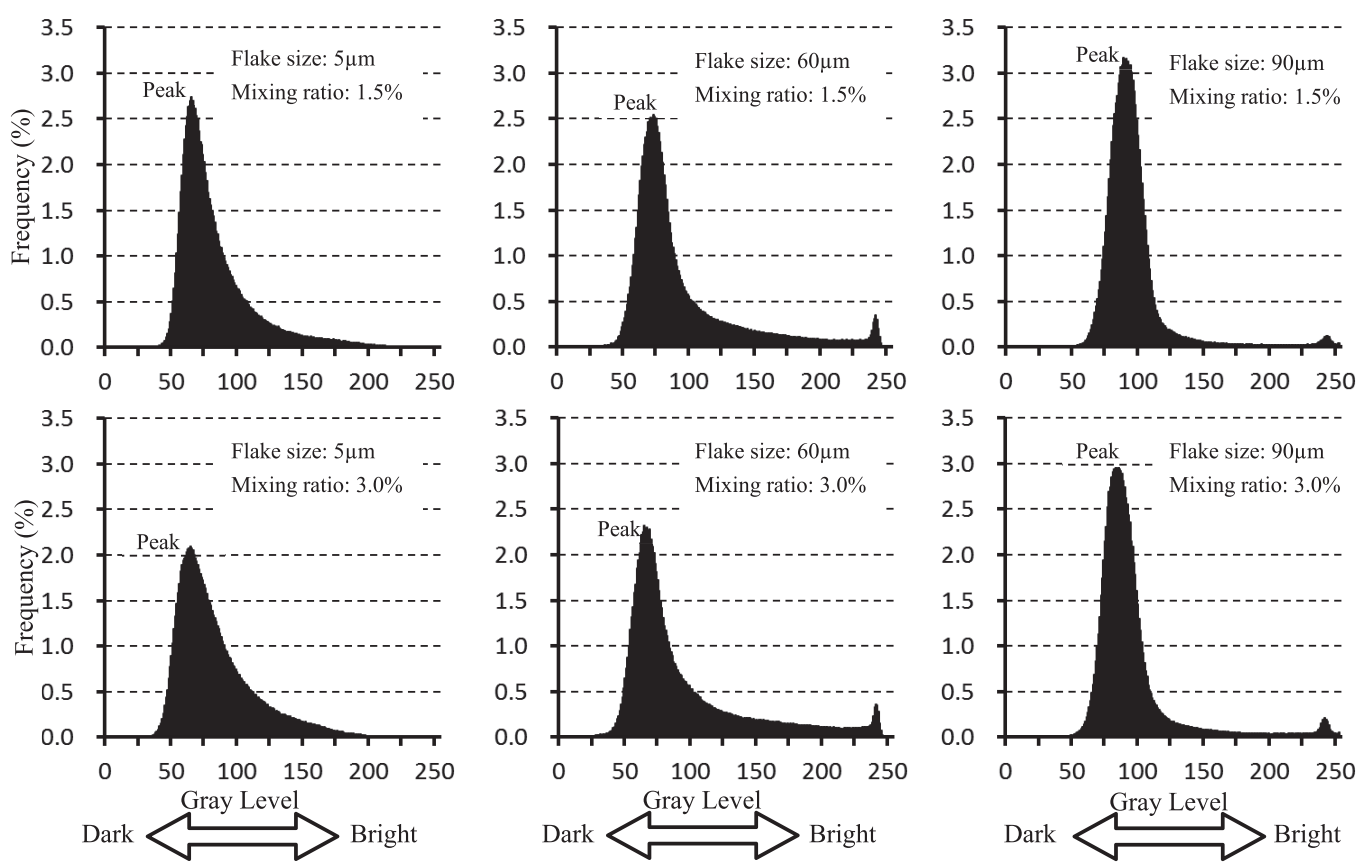

Fig. 7 Gray level histograms for various sizes and mixing ratios of flake

結果として，図 2 で例示したように濃度の分布が相対的に 平準化して図 8 に示したピークの高さが下がり, 図 9 に示 した歪度も低下したと考えられる．粒径の変化による影響 については，粒径の大きい画像の方が粒子間の隙間が多い ために樹脂領域の面積が広がり, その結果として, 図 8 に おけるピーク值の上昇や図 9 における歪度の増加につな がったと考えられる。

\section{3 同時生起行列による解析結果}

図 10 に角 2 次モーメントの算出結果を示す. 各条件に ついて 6 枚の画像解析結果の平均值と標準偏差を示した. 粒径は同一で混合比が異なる条件の平均值同士を比較した 結果, 粒径 $5 \mu \mathrm{m}$ と粒径 $60 \mu \mathrm{m}$ においては危険率 $1 \%$ の 有意差が見られた. 粒径 $90 \mu \mathrm{m}$ においては平均值が減少 したものの有意差は認められなかった. 粒径 $90 \mu \mathrm{m}$ にお いては標準偏差も大きかった.すなわち粒径 $5 \mu \mathrm{m}$ と 60 $\mu \mathrm{m}$ においては, 混合比の増加に伴い角 2 次モーメントの 值が減少した。

混合比は同一で粒径が異なる条件の平均值同士を比較し た結果，全ての条件の比較について危険率 $1 \%$ の有意差 が見られた.すなわち粒径の増大に伴って角 2 次モーメン トの值が増加した.

図 11 にエントロピーの算出結果を示す. 各条件につい て 6 枚の画像解析結果の平均值と標準偏差を示した. 粒径 は同一で混合比が異なる条件の平均值同士を比較した結果, 全ての粒径において危険率 $1 \%$ の有意差が見られた.す なわち全ての粒径において, 混合比の増加に伴いエントロ ピーの值が増加した。

混合比は同一で粒径が異なる条件の平均值同士を比較し た結果, 粒径 $5 \mu \mathrm{m}$ と $60 \mu \mathrm{m}$ の比較においては, 混合比 $1.5 \%$, 混合比 $3.0 \%$ ともに有意差は見られなかった. 粒 
径 $90 \mu \mathrm{m}$ と他の粒径との比較においては，混合比 $1.5 \%$, 混合比 $3.0 \%$ ともに有意差が見られた.

角 2 次モーメントの定義式(2)より，同時生起行列におい て特定の濃度対が多いとき，すなわち，同時生起行列のあ

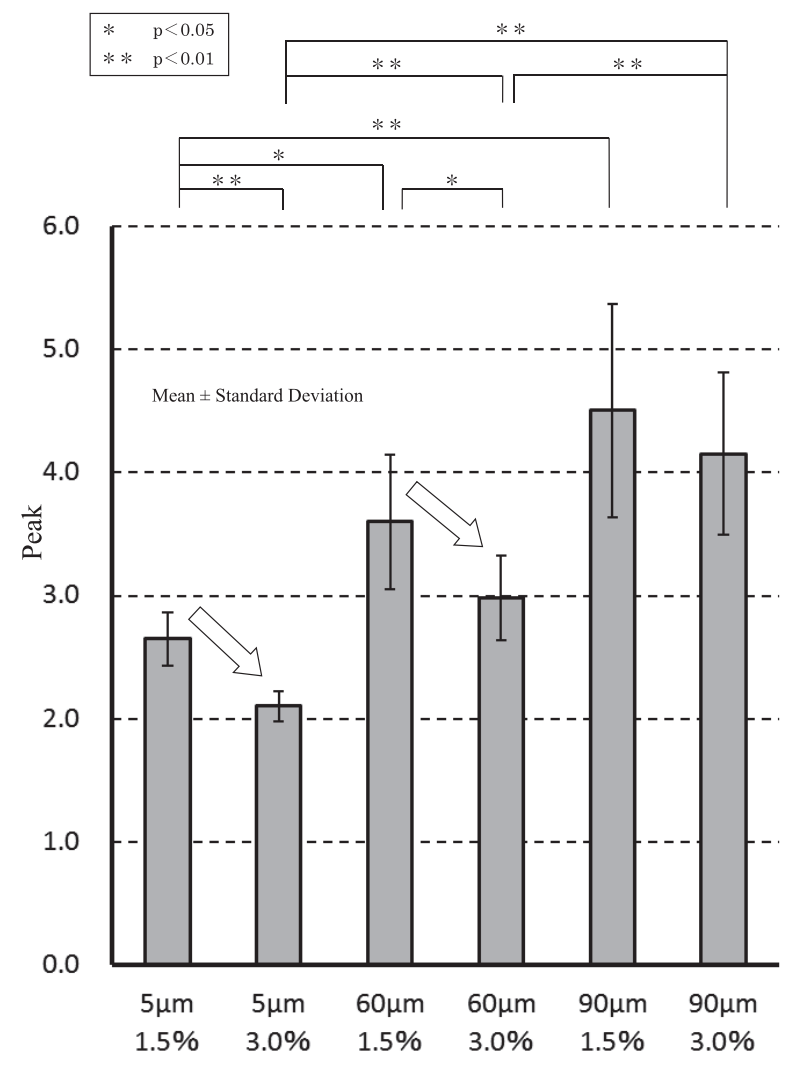

Fig. 8 Peak

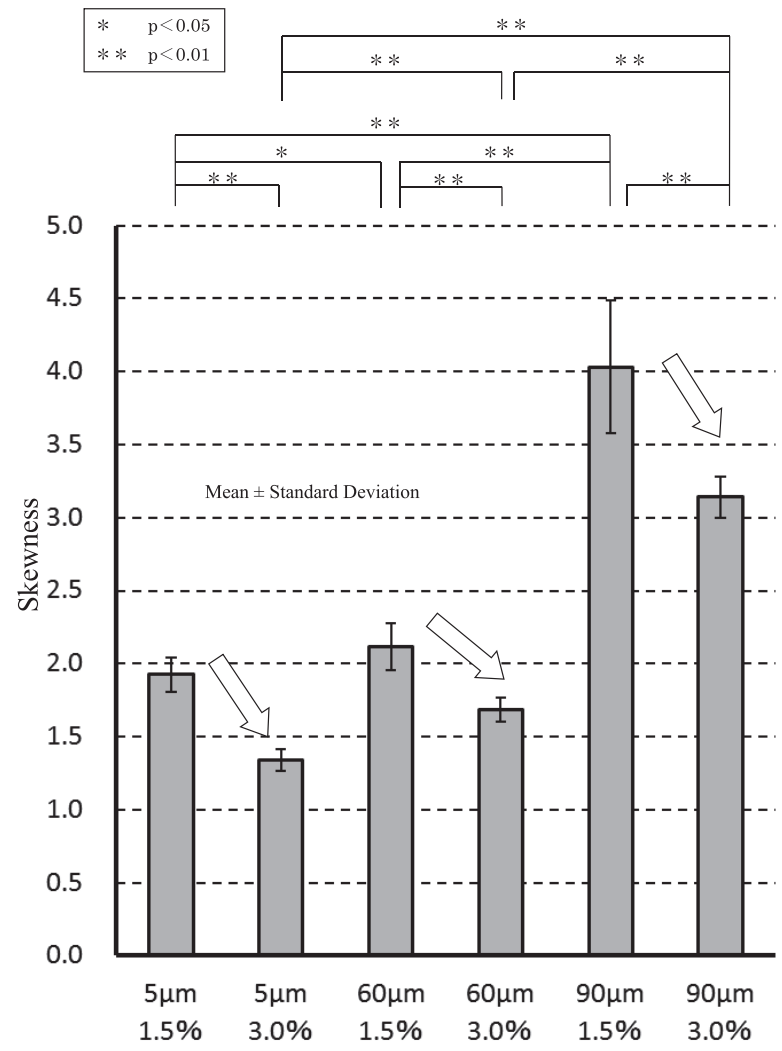

Fig. 9 Skewness
る要素が大きな值になるときに角 2 次モーメントの值が大 きくなる，またエントロピーの定義式(3)より，同時生起行 列において各濃度対が一様に存在するとき，すなわち，同 時生起行列の各要素が近い值になるときにエントロピーの 值が大きくなる．粒径 $5 \mu \mathrm{m}$ と $60 \mu \mathrm{m}$ においては，混合 比を増加した場合に，濃度ヒストグラムにおけるピークの 值が低下した結果，同時生起行列の要素の差が相対的に減 少して表 2 で例示したように角 2 次モーメントの減少やエ ントロピーの増加につながったものと考えられる.

図 10〜11 の解析結果と図 4〜6の画像との関係性を検討 すると，以下のように考えられる．3.2でも述べたように， 混合比の変化に関する影響に関しては, 混合比が増加する と表層のみならず内部の粒子も増加して，表面からの画像 として見たときには様々な濃さの粒子として画像に表れ， また粒子間の隙間も少ない画像となった。表 2 で例示した ように，画像内における色の組合せのバリエーションが多 いときには角 2 次モーメントは低下しエントロピーは増大 する．混合比の増加によって様々な濃さの粒子が増えた結 果として組合せのバリエーションが増え, 図 10 に示した 角 2 次モーメントが低下し図 11 に示したエントロピーが 増大したと考えられる．粒径の変化による影響については, 粒径の大きい画像の方が粒子間の隙間が多いため，樹脂領 域の面積が広がり，その結果として色の組合せのバリエー ションが減少して図 10 における角 2 次モーメントの増加 につながったと考えられる。

また，粒径が大きい $90 \mu \mathrm{m}$ の画像については解析結果 の平均值が変化したものの有意差が出ない項目があり，ま た標準偏差が大きくなる傾向となった. $90 \mu \mathrm{m}$ の画像で は粒子間の隙間が大きくなっていることから，本手法では

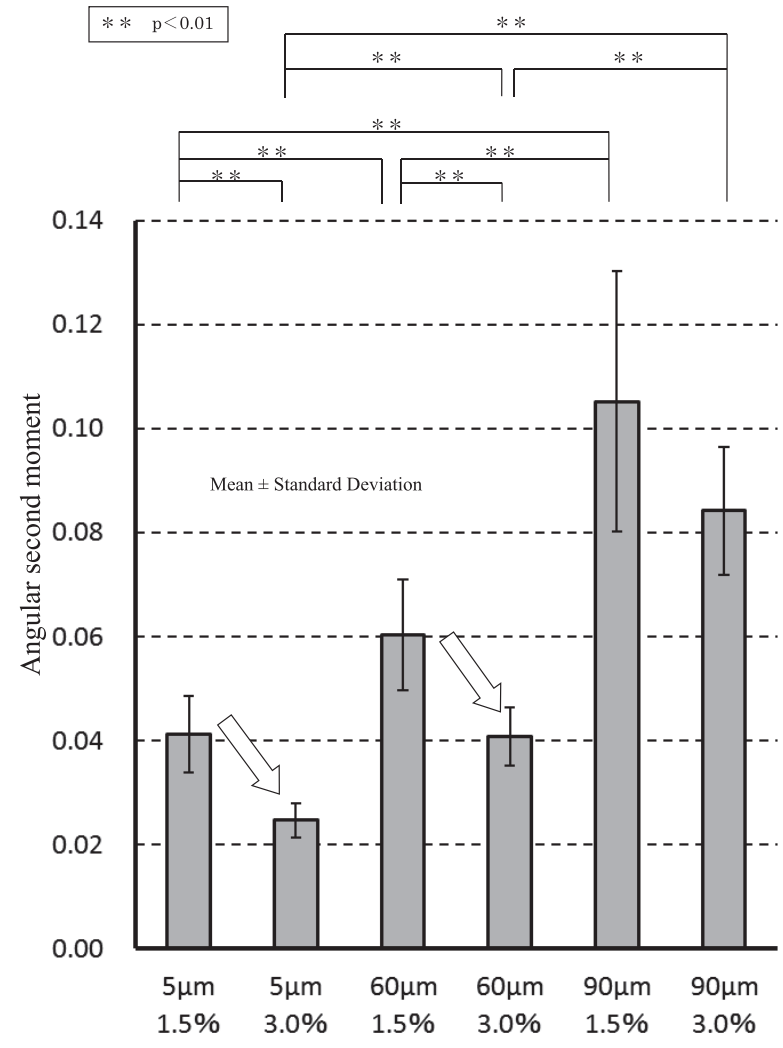

Fig. 10 Angular second moment 
隙間の大きい画像に対しては解析結果がばらつくおそれが あると考えられる。ばらつきを抑制するためには，粒径に 合わせた撮像倍率の選定といった撮像条件の更なる検討が 必要であると考えられる.

上記の算出結果を歪度, 角 2 次モーメントおよびエント ロピーを座標軸とする 3 次元座標にプロットしたものを図 12 に示す. 混合比の増加に着目すると粒径 $5 \mu \mathrm{m}$ と $60 \mu \mathrm{m}$ においてはすべての項目について画像解析結果が変化する 傾向が認められた．粒径 $90 \mu \mathrm{m}$ においては歪度やエント ロピーが変化する傾向が認められた。

以上のように, 同一粒径の画像同士に関して, 混合比の 違いによって画像の濃度分布が変化した結果, 画像処理結 果に影響を及ぼしたと考えられる. 本手法の更なる検討に より混合比や粒径による光輝材の分散状態の変化が識別で

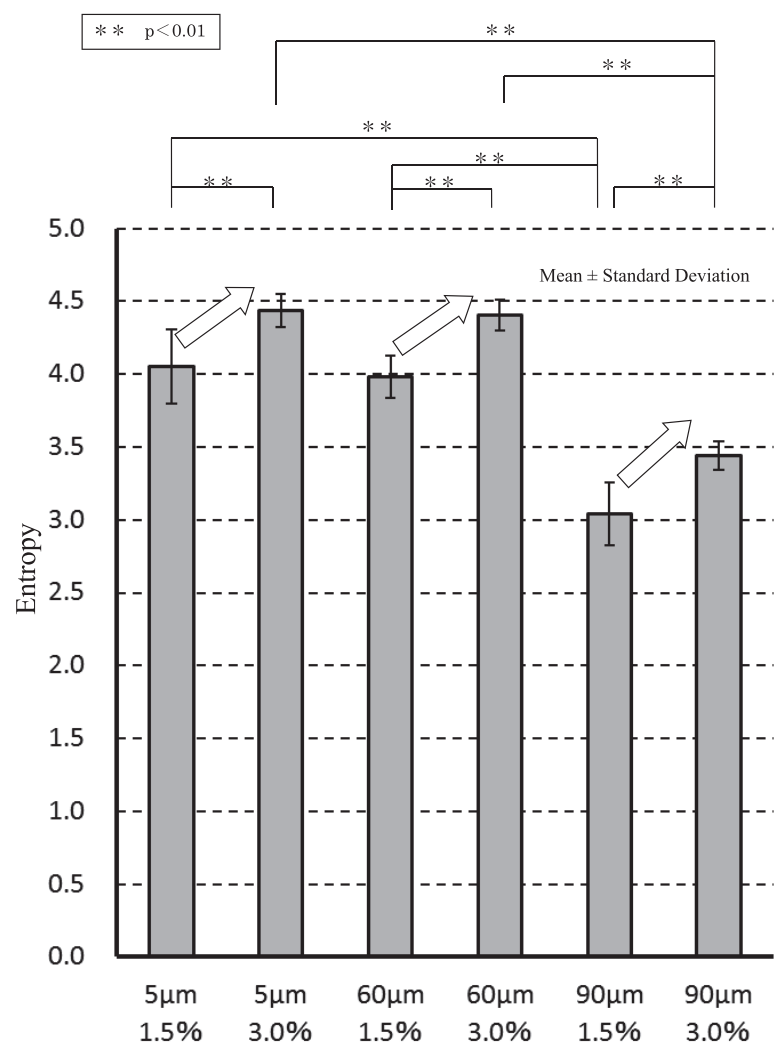

Fig. 11 Entropy
きれば，光輝材分散状態の評価へ展開できるのではないか と考えられる.

本研究においては, 表 1 のとおり材料メーカーが提示し ている光輝材の寸法をそのまま用いたが, 成形過程におけ る光輝材寸法の変化も考慮する必要があると考えられる. 繊維強化樹脂においては, 射出成形の過程において破断等 によって繊維の寸法が変化するという報告があるため ${ }^{25}$, 光輝材寸法も同様に変化することが想定される. 光輝材分 布を画像解析で正確に表現していくためには, 成形過程に おける光輝材寸法の変化も検討しておく必要があると考え られる。

\section{4. 結 言}

本研究では, 光輝材を樹脂に混合したものを射出成形す ることにより，塗装工程を省きつつメタリック調の外観を 発現する射出成形品の生産技術（メタリック成形）に関す る光輝材の局所的な分散状態を評価するための基礎的な検 討を行った. 評価の方法として，これまでメタリック成形 品に適用されたことがなかった濃度ヒストグラムと同時生 起行列といった画像解析手法を使用した. 数種類の粒径の 光輝材に対して混合比を変化させた試験片を CCD マイク ロスコープで撮影して得られた画像の解析結果を比較した. その結果を以下に記す。

（1）光輝材の混合比が増加した結果, 表面近傍の粒子が増 えたことが示唆された。濃度ヒストグラムにおいては, 粒径 $5 \mu \mathrm{m}$ と $60 \mu \mathrm{m}$ においてピークの值が低下した. また全ての粒径について歪度が減少した。同時生起行列 の解析結果から, 粒径 $5 \mu \mathrm{m}$ と $60 \mu \mathrm{m}$ において角 2 次 モーメントは減少し, 全ての粒径についてエントロピー は増加した。

（2）光輝材の粒径が増大した結果，濃度ヒストグラムにお いては, 歪度が増加した. 同時生起行列の解析結果から, 角 2 次モーメントが増加した。

（3）混合比や粒径の違いによって画像の濃度分布が変化し， 画像解析結果に影響を及ぼしたと考えられる。

(4) 光輝材分散状態の評価における濃度ヒストグラムと同 時生起行列の適用可能性が示唆された.

以上のように，光輝材の粒径が同一の試験片において， 混合比の違いによる粒子の増減から画像解析結果が変化し,
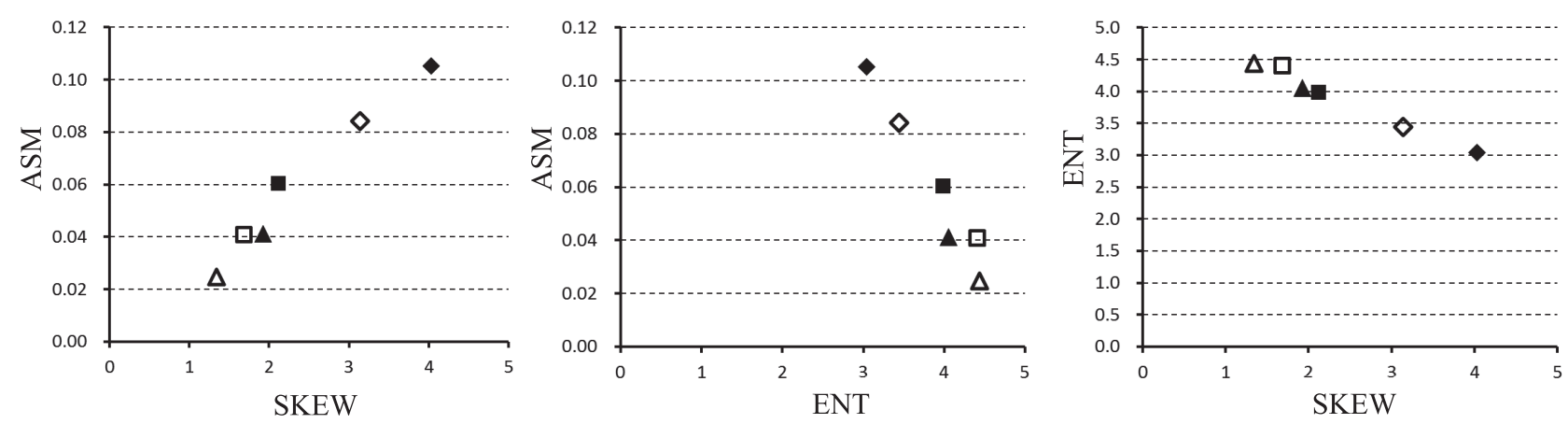

\begin{tabular}{|llllll|}
\hline$\Delta 5.0 \mu \mathrm{m}$ & $1.5 \%$ & $\square 60 \mu \mathrm{m}$ & $1.5 \%$ & $\diamond 90 \mu \mathrm{m}$ & $1.5 \%$ \\
$\triangle 5.0 \mu \mathrm{m}$ & $3.0 \%$ & $\square 60 \mu \mathrm{m}$ & $3.0 \%$ & $\diamond 90 \mu \mathrm{m}$ & $3.0 \%$ \\
\hline
\end{tabular}

Fig. 12 Scatterplot of the result of image analysis 
成形品から得られた特性值を用いて光輝材分散状態を定量 的に識別できた. 数種類の粒径に対して同様の結果が得ら れた. 光輝材分散状態の変化が画像解析によって捉えられ たことから，メタリック成形品における光輝材分散状態の 定量的な評価の可能性が示唆された.

今後の課題としては, 現時点では限定的な粒径や混合比 についての結果が得られたが, メタリック成形品における 様々な混合比や粒径に対する光輝材分散状態の本格的な評 価に適用するためにはサンプル数を増やした更なる検討が 必要である。また, 粒径の大きい画像については標準偏差 が大きくなる傾向となったことから，ばらつきを抑制する ための撮像倍率等の撮像条件の更なる検討が必要である. 様々なメタリック成形品に対する計測事例を増やしてデー 夕処理方法についての更なる検討を加えて, 照明をはじめ とする撮像条件の最適化や目視による評価との比較を進め たい.さらに成形過程における光輝材寸法の変化を考慮し た詳細な検討を行いたい. そして光輝材の配向が原因とな る色ムラの識別への適用を検討したい. また，他の複合材 料におけるフィラーの分散状態評価や，ガス焼けやウェル ドラインなどの一般的な外観不良評価への展開も視野に入 れていきたい.

\section{謝 辞}

本研究の一部は, 経済産業省平成 22 年度戦略的基盤技 術高度化支援事業により遂行されたものであることを示し， 謝意を表します。

\section{参 考 文 献}

1 ）佐藤豊, 金丸哲郎：色材協会誌，52(6)，311(1979)

2 ）永野裕幸：色材協会誌， 78(8)，372(2005)

3 ）西村幸男：表面技術，56(10)，594(2005)

4 ）秋元英郎：成形加工, 23(11)，638(2011)

5 ) 和田明紘, 川端繁忠：成形加工，3(2)，165(1991)
6 ）田中秀雄, 舘山弘文, 鈴木淳広 : 成形加工, $5(2), 107$ (1993)

7 ) 片岡紘, 梅井勇雄, 加藤厳生 : 成形加工, 9 (11), 889 (1997)

8 ）岩沢知幸, 福島祥夫, 黒岩広樹, 石月言義, 桐生英幸 : 成形加工' 11，91(2011)

9 ）村田泰彦：成形加工，23(12)，700(2011)

10) Renou, N. and Feigenblum, J.：成形加工, 23(12), 705 (2011)

11）今泉賢：成形加工，23(12)，711(2011)

12) 戸田直樹：成形加工，23(12)，718(2011)

13）中井秀, 荻野輝明：成形加工シンポジア’ 11, 137 (2011)

14）道井貴幸, 大島順敏, 瀬戸雅宏, 山部昌, 石川達夫： 成形加工，17(5)，349(2005)

15）多比良恵, 滝克彦, 横井英俊：成形加工'12, 127 (2012)

16）五十嵐浩史，竹内徹：塗装工学，40（9)，339(2005)

17）瀬戸口俊一：塗装工学，45(3)，125(2010)

18）関根英樹, 鈴木寛, 山本圭介：日本機械学会論文集 $(\mathrm{A}$ 編)，62(594)，313(1996)

19）川村宗弘, 守田了, 田中稔, 橘輝夫：成形加工, 9 (11)，913(1997)

20）安井平司, 田中勇輔, 丸尾賢二, 神谷隆仁, 坂本竜司 郎：精密工学会誌, 74(12)，1313(2008)

21) Haralick, R. M., Shanmugam, K. and Dinstain, I. : IEEE Trans. Systems, Man and Cybernetics, 3(6), 610 (1973)

22）加藤和彦, 五百井俊宏, 松永正久, 井口信明 : 精密工 学会誌, 63(2), 208(1997)

23）森俊夫, 脇田登美司, 遠藤善道 : 繊維学会誌, $55(9), 424$ (1999)

24）樋口静一, 本橋康之 : 精密工学会誌, 70 (8), 1059 (2004)

25）小川俊夫, 美馬正道, 田矢直紀：成形加工, 7(5), 315 (1995) 